ISSN 1392-3196 / e-ISSN 2335-8947

Zemdirbyste-Agriculture, vol. 102, No. 2 (2015), p. 153-158

DOI $10.13080 / \mathrm{z}-\mathrm{a} .2015 .102 .020$

\title{
Variability of nuclear DNA content and agromorphological characteristics of switchgrass (Panicum virgatum L.) germplasm in Lithuania
}

\author{
Giedrẻ DABKEVIČIENĖ, Nijolè LEMEŽIENĖ, Eglè NORKEVIČIENĖ, Žilvinas LIATUKAS, \\ Jurgita CESEVIČIENĖ, Rita ARMONIENĖ, Bronislava BUTKUTE் \\ Institute of Agriculture, Lithuanian Research Centre for Agriculture and Forestry \\ Instituto 1, Akademija, Kèdainiai distr., Lithuania \\ E-mail: giedre@1zi.lt
}

\begin{abstract}
While searching for novel energy plants, researchers have become interested in switchgrass (Panicum virgatum L.), which is a C4 perennial grass. The objective of this study was to assess switchgrass populations by estimating the variability of nuclear DNA content and agromorphological characteristics.

Plant ploidy level was determined using a flow cytometry technique. The switchgrass collection comprised 31 populations differing in ploidy level. Seventeen populations were tetraploid with an average genomic DNA content of 2.5 picograms (pg). The individuals of 4 populations were found to have an average DNA content of $5.4 \mathrm{pg}$, which is specific to octoploids. The remaining 10 populations were estimated to be of a mixed ploidy level with DNA content ranging from 2.1 to $7.0 \mathrm{pg}$. The plants of tetraploid and mixed ploidy populations were characterised by significantly taller culms and more abundant fresh biomass production compared with octoploid populations. An analysis of dry matter revealed a similar trend. Earlier heading date was observed for tetraploid populations. All switchgrass populations tested exhibited a similar overwinter survival rate $(93.7-96.7 \%)$. The most stable characteristics were found to be plant height, bunch diameter, leaf width and length (coefficient of variation 4.09.7\%). Among all plant characteristics, the greatest variability was established for dry biomass yield (coefficient of variation $5.0-35.8 \%$ )
\end{abstract}

Key words: agromorphological characteristics, ploidy level, switchgrass, wild populations.

\section{Introduction}

Search for and research on energy plants used for biofuel production is currently one of the most rapidly developing alternative energy realms. In Lithuania, intensive efforts have been focused in recent years to identify perennial grasses suitable for conversion into biofuel. Attention has been drawn to switchgrass (Panicum virgatum L.), a C4 perennial grass, which is used worldwide, especially in the USA, for combustion and as a feedstock for the second generation bioethanol and biogas production (Black, 1971; Beale, Long, 1995; Fay et al., 2003).

The world switchgrass collection includes commercial varieties, breeding lines and two distinct groups of wild ecotypes - the upland and the lowland, which differ not only in agrobiological and phenotypic characteristics but also in ploidy level (Alexopoulou et al., 2008; Casler, 2010). There is information about agrobiological characteristics of switchgrass varieties, chromosome number in them and their suitability for combustion.

Switchgrass is a perennial grass which can be grown across a wide geographic range. Only ornamental forms of switchgrass are currently grown in Lithuania. Switchgrass is cross-pollinating, highly heterozygous species with multiple ploidy levels ranging from $2 \mathrm{n}=2 \mathrm{x}=18$ to $2 \mathrm{n}=12 \mathrm{x}=108$ (Parrish, Fike, 2005; Narasimhamoorthy et al., 2008). Tetraploid $(2 n=4 x=36)$ and octoploid $(2 \mathrm{n}=8 \mathrm{x}=72)$ ecotypes are the mostcommon. These two groups of ecotypes differ in both agrobiological and phenological characteristics (Casler, 2012). Some researchers maintain that such division into two separate groups is inaccurate (Missaoui et al., 2006; Zhang et al., 2011 a), because of the existence of the intermediate (hybrid) group of ecotypes for which stable level of ploidy is not inherent (Vogel, Mitchell, 2008; Zhang et al., 2011 b). It is believed that an increase in chromosome number in polyploid plant populations enhances the level of heterozygosity and creates prerequisites for better adaptation of the species, i.e. increases its adaptability across a broad geographic range (Parisod et al., 2010; Delaney, Baack, 2012). For breeding, seed production and maintenance of collections it is essential that the populations of switchgrass of different ploidy level are isolated from one another in order to prevent interpopulation crossing (Delaney, Baack, 2012). 
A numerous collection of germplasm of switchgrass varieties and wild ecotypes obtained from the Plant Genetic Resources Conservation Unit of the United States Department of Agriculture and Agricultural Research Service has opened up possibilities for identification of the most promising material for cultivation under Lithuania's conditions. The wild switchgrass populations are expected to be an especially highly valuable material, since they are characterised by higher phenotypic and genotypic polymorphism than commercial varieties, which is a valid basis for deeper genetic research and for envisaging future directions in switchgrass breeding. Our study is the first attempt in Lithuania to estimate the genetic switchgrass collection with a focus on the variability of nuclear DNA content and agromorphological characteristics.

\section{Material and methods}

Experiments were conducted in the Central Lowland of Lithuania $\left(55^{\circ} 23^{\prime} 49^{\prime \prime} \mathrm{N}, 23^{\circ} 51^{\prime} 40^{\prime \prime} \mathrm{E}\right)$, at Institute of Agriculture, Lithuanian Research Centre for Agriculture and Forestry during 2012-2013. The investigations were carried out at the Department of Grass Breeding and the Laboratory of Genetics and Physiology. Seeds for the germplasm collections of switchgrass were obtained from Plant Genetic Resources Conservation Unit (PGRCU) of the United States Department of Agriculture and Agricultural Research Service. The collection was composed of wild upland populations originated from North Dakota.

Plant ploidy level was estimated using a flow cytometer (Partec GmbH, Germany) (Lu et al., 1998). The analysis was performed in plant leaf tissue. Based on the manufacturer's instructions, the following regime was selected: gain $=700, \mathrm{~L}-\mathrm{L}=20$, speed $=1$. The data from the flow cytrometric analysis were used to estimate plant genome size, i.e. nuclear DNA (deoxyribonucleic acid) content expressed in picograms (pg). The standard used for the comparison was wheat (Triticum spp.) with a known nuclear DNA content $(2 \mathrm{n}=32 \mathrm{pg})$ (Johnston et al., 1999), which in our study corresponded to the cytometer's peak position at reading 236 . The formula used for converting fluorescence values to DNA content was: nuclear DNA content $=($ mean position of unknown peak $) /($ mean position of known peak $) \times$ DNA content of known standard (Pecinka et al., 2006; Narasimhamoorthy et al., 2008). For ploidy level establishment, DNA content was analysed in 6-8 plants of each population.

The genetic collection of switchgrass under study was set up using the seedlings grown in a greenhouse. At the beginning of June, 28 seedlings per accession $(2$ replications, $14 \times 2$ ) were planted in the field at $50 \times 50 \mathrm{~cm}$ distances. Average fresh biomass yield per plant (g) for the first and second cuts was determined having weighed all plants per plot of each replication. Dry biomass yield per plant was calculated from the data of fresh herbage mass, dry biomass content and plant number per plot. For dry biomass content, herbage samples of $0.5 \mathrm{~kg}$ were oven-dried at $105^{\circ} \mathrm{C}$ to a constant weight. The first cut was taken at the beginning of heading stage of each accession, the second cut after regrowth of aftermath. The following agromorphological characteristics were determined: overwinter survival rate, $\%$, earliness (heading date), plant height, $\mathrm{cm}$ (at booting stage), number of culms (at heading stage), bunch diameter (after the second cut), leaf width and length (at seed ripening stage).

The statistical analysis of the experimental data was done using software ANOVA, STAT from the package SELEKCIJA and IRRISTAT (Tarakanovas, Raudonius, 2003).

\section{Results and discussion}

Previous studies have reported that the lowland populations are exclusively tetraploid, whereas the upland type can vary in ploidy (tetraploid, heksaploid and octoploid), both within and among populations (Narasimhamoorthy et al., 2008; Costich et al., 2010; Zalapa et al., 2011, Zhang et al., 2011 b; Lu et al., 2013). Our results also showed that switchgrass collection varied in ploidy between populations.

In the plants of many populations (17, i.e. $54.8 \%$ ), nuclear DNA content averaged $2.5 \mathrm{pg}$ (ranged from 2.1 to $3.3 \mathrm{pg}$ ). We clustered these populations into the group of tetraploid $(2 n=4 x=36)$ populations. In the switchgrass individuals of four populations (12.9\%), we established the nuclear DNA content on average $5.4 \mathrm{pg}$ $(5.0-5.7 \mathrm{pg})$, which is specific to octoploid $(2 \mathrm{n}=8 \mathrm{x}=72)$ plants (Table 1).

The remaining 10 tested populations $(32.3 \%)$ were of mixed ploidy. These populations were composed of different ploidy plants. Analysis of 74 plants showed that 21 individuals were tetraploid, 5 - hexaploid (average DNA content $4.2 \mathrm{pg}$, from 4.1 to $4.5 \mathrm{pg}$ ), 8 - octoploid, 17 - decaploid (average DNA content $6.5 \mathrm{pg}$, from 5.6 to $7.0 \mathrm{pg}$ ). Various nuclear DNA content was determined in 23 remaining plants. DNA content ranged from 2.1 to $7.0 \mathrm{pg}$. In these samples cytometer showed two peaks corresponding to different ploidy levels.

$\mathrm{Lu}$ et al. (1998) and Narasimhamoorthy et al. (2008) have suggested that $2 \mathrm{n}$ nuclear DNA content in tetraploid switchgrass plants averages $3.1 \mathrm{pg}$ and in octaploid plants $6.1 \mathrm{pg}$. Previous studies have reported that DNR content in nucleus of tetraploid plants was 3.1 pg and octoploid - 5.2 pg (Costich et al., 2010; Casler, 2012). Hopkins et al. (1996) indicated that the nuclear DNA content for tetraploid switchgrass plants varied in the range of 2.7 to $3.2 \mathrm{pg}$ (on average $3.1 \mathrm{pg}$ ) and that of octoploids ranged from 4.8 to $5.8 \mathrm{pg}$ (on average $5.2 \mathrm{pg})$.

Our results agree with the findings of other studies. Narasimhamoorthy et al. (2008) are consistent that a large proportion of switchgrass ecotypes growing in Central America territories have mixed ploidy levels. Aneuploidy is observed in the populations with a higher ploidy level, which results in fertility reduction in their progeny and even higher genomic instability (Zhang et al., 2011 b). The diploid set of chromosomes $(2 \mathrm{n}=2 \mathrm{x}=18)$ in switchgrass populations is very rare (Zhang etal., 2011 b). Successful breeding is only possible when populations of the same ploidy level are hybridised (Hopkins et al., 1996), while crosses between the populations of different ploidy levels typically result in inhibited seed set or production of abnormal seed. Nonetheless, the populations of mixed ploidy are interesting in the studies on the genetic species diversity and evolution. 
Table 1. The nuclear DNA content and ploidy level of investigated switchgrass populations

\begin{tabular}{|c|c|c|c|c|}
\hline $\begin{array}{l}\text { Lithuanian } \\
\text { catalogue } \\
\text { number }\end{array}$ & $\begin{array}{c}\text { PGRCU } \\
\text { catalogue number }\end{array}$ & Ploidy level & $\begin{array}{c}\text { Number } \\
\text { of plants } \\
\text { per accession }\end{array}$ & $\begin{array}{c}\text { Average DNA content } \\
\text { in pg }\end{array}$ \\
\hline \multicolumn{5}{|c|}{ Tetraploid populations } \\
\hline 24 & PI $64231001 \mathrm{SD}$ & $4 \mathrm{x}$ & 8 & 2.4 \\
\hline 25 & PI $64231101 \mathrm{SD}$ & $4 \mathrm{x}$ & 8 & 2.8 \\
\hline 26 & PI $64231201 \mathrm{SD}$ & $4 \mathrm{x}$ & 8 & 2.3 \\
\hline 30 & PI $64229201 \mathrm{SD}$ & $4 \mathrm{x}$ & 7 & 2.1 \\
\hline 31 & PI $64229301 \mathrm{SD}$ & $4 \mathrm{x}$ & 8 & 2.5 \\
\hline 33 & PI $64229101 \mathrm{SD}$ & $4 \mathrm{x}$ & 7 & 2.6 \\
\hline 42 & PI $64228601 \mathrm{SD}$ & $4 \mathrm{x}$ & 8 & 2.3 \\
\hline 47 & PI $64229601 \mathrm{SD}$ & $4 \mathrm{x}$ & 8 & 2.2 \\
\hline 50 & PI $64229901 \mathrm{SD}$ & $4 \mathrm{x}$ & 8 & 2.6 \\
\hline 57 & PI $64230601 \mathrm{SD}$ & $4 \mathrm{x}$ & 7 & 3.2 \\
\hline 104 & PI $64223201 \mathrm{SD}$ & $4 \mathrm{x}$ & 8 & 2.5 \\
\hline 105 & PI $64223301 \mathrm{SD}$ & $4 \mathrm{x}$ & 8 & 2.6 \\
\hline 106 & PI $64223401 \mathrm{SD}$ & $4 \mathrm{x}$ & 8 & 2.1 \\
\hline 107 & PI $64223501 \mathrm{SD}$ & $4 \mathrm{x}$ & 8 & 2.5 \\
\hline 127 & PI $64225901 \mathrm{SD}$ & $4 \mathrm{x}$ & 8 & 3.1 \\
\hline 130 & PI $64226201 \mathrm{SD}$ & $4 \mathrm{x}$ & 8 & 3.3 \\
\hline 134 & PI $64226601 \mathrm{SD}$ & $4 \mathrm{x}$ & 8 & 2.1 \\
\hline \multicolumn{5}{|c|}{ Octoploid populations } \\
\hline 113 & PI $64224201 \mathrm{SD}$ & $8 \mathrm{x}$ & 8 & 5.6 \\
\hline 114 & PI $64224301 \mathrm{SD}$ & $8 \mathrm{x}$ & 7 & 5.3 \\
\hline 119 & PI $64924901 \mathrm{SD}$ & $8 \mathrm{x}$ & 7 & 5.7 \\
\hline 129 & PI $64226101 \mathrm{SD}$ & $8 \mathrm{x}$ & 8 & 5.0 \\
\hline \multicolumn{5}{|c|}{ Mixed ploidy levels populations } \\
\hline 116 & PI $64224501 \mathrm{SD}$ & $4 x / 10 x / 8 x+4 x^{*}$ & $2 / 3 / 2$ & $3.2 / 7.0 / 4.5+2.7^{* *}$ \\
\hline 118 & PI $64224701 \mathrm{SD}$ & $6 x / 8 x+4 x$ & $4 / 2$ & $4.5 / 5.1+2.1$ \\
\hline 115 & PI $64224401 \mathrm{SD}$ & $4 x 10 x / 10 x+4 x$ & $1 / 6 / 1$ & $2.5 / 7.0 / 5.6+2.6$ \\
\hline 53 & PI $64230201 \mathrm{SD}$ & $4 x / 10 x / 10 x+6 x$ & $4 / 1 / 3$ & $3.2 / 6.9 / 6.7+3.8$ \\
\hline 125 & PI $64225701 \mathrm{SD}$ & $4 \mathrm{x} / 10 \mathrm{x}$ & $7 / 1$ & $3.3 / 6.6$ \\
\hline 112 & PI $64224001 \mathrm{SD}$ & $8 x / 10 x+4 x$ & $4 / 2$ & $5.7 / 5.8+2.7$ \\
\hline 117 & PI $64224601 \mathrm{SD}$ & $10 x / 10 x+4 x$ & $6 / 1$ & $6.7 / 5.6+2.6$ \\
\hline 124 & PI $64225601 \mathrm{SD}$ & $4 x / 8 x+4 x$ & $2 / 6$ & $3.2 / 4.9+2.7$ \\
\hline 126 & PI $64225801 \mathrm{SD}$ & $4 x / 6 x+4 x$ & $5 / 3$ & $3.2 / 4.5+2.6$ \\
\hline 32 & PI $64229401 \mathrm{SD}$ & $6 x / 10 x+6 x$ & $5 / 3$ & $3.9 / 7.0+4.1$ \\
\hline
\end{tabular}

Note. PGRCU - Plant Genetic Resources Conservation Unit; * and ** - corresponding ploidy levels and DNA content in plants, with various DNA content in leaf tissues.

Dhooghe et al. (2011) suggest that for the determination of ploidy it is expedient to use a considerably more effective technique - flow cytometry, while the conventional chromosome count method should be employed for the verification of ploidy results. We agree with Hopkins et al. (1996), who maintain that flow cytometry is a suitable technique to distinguish tetraploid individuals from octoploid ones, while in order to identify diploid, hexsaploid and aneuploid individuals it is recommended to apply a direct chromosome count in cytological preparations.

Researchers have expressed rather divergent views regarding the relationship between ploidy level and agromorphological characteristics of switchgrass populations. Casler (2005) has pointed out that analysis of morphological characteristics is an effective tool for discriminating between tetraploid and octoploid populations, whereas Lowry et al. (2014) have stated that many researchers have not discerned the correlation between plant characteristics and ploidy level.

A number of researchers have reported the plants of tetraploid populations to be taller compared to those of octoploid populations (Cortese et al., 2010; Zhang et al., 2011 a).

Our research evidence agrees with this proposition. The plants in our tetraploid and mixoploid populations had significantly $(P<0.05)$ taller culms. Plants in tetraploid populations formed significantly $(P<0.05)$ more stems, compared with octoploid and mixed ploidy plants (Table 2). According to bunch diameter and leaf width, all the three groups of populations were very similar, leaf length of tetraploid plants lagged behind the octoploids and mixed ploidy level plants (on average $3.6 \mathrm{~cm}$ shorter).

We established the within-population variation of plant characteristics. Plant height, leaf width and length, bunch diameter parameters varied little or moderately (CV 4.6-11.3\%) in all populations. The stems number variation rate was medium (CV 13.1\%) in mixed ploidy plants, while in populations of tetraploids and octoploids it was high (CV 20.7-29.9\%).

Fresh and dry biomass yield is one of the major indicators of plant productivity (Table 3 ). The average data of the first cut and annual yield $\left(1^{\text {st }}+2^{\text {nd }}\right.$ cuts $)$ 
Table 2. Diversity of agromorphological characteristics in the populations of switchgrass differing in ploidy level

\begin{tabular}{ccccccccccc}
\hline \multirow{2}{*}{ Ploidy level } & $\begin{array}{c}\text { Plant height } \\
\mathrm{cm}\end{array}$ & \multicolumn{2}{c}{ Number of culms } & $\begin{array}{c}\text { Bunch diameter } \\
\mathrm{cm}\end{array}$ & \multicolumn{2}{c}{$\begin{array}{c}\text { Leaf width } \\
\mathrm{cm}\end{array}$} & \multicolumn{3}{c}{$\begin{array}{c}\text { Leaf length } \\
\mathrm{cm}\end{array}$} \\
\cline { 2 - 12 } & Mean $\pm \mathrm{SE}$ & $\mathrm{CV}$ & Mean $\pm \mathrm{SE}$ & $\mathrm{CV}$ & Mean $\pm \mathrm{SE}$ & $\mathrm{CV}$ & Mean $\pm \mathrm{SE}$ & $\mathrm{CV}$ & Mean $\pm \mathrm{SE}$ & $\mathrm{CV}$ \\
\hline Tetraploid & $115.8 \pm 2.4 \mathrm{a}^{*}$ & 8.6 & $72.3 \pm 3.6 \mathrm{a}$ & 20.7 & $18.9 \pm 0.5$ & 11.3 & $9.8 \pm 0.10$ & 4.6 & $42.7 \pm 1.0 \mathrm{a}$ & 9.7 \\
Octoploid & $97.3 \pm 1.9 \mathrm{~b}$ & 4.0 & $64.6 \pm 9.7 \mathrm{~b}$ & 29.9 & $17.9 \pm 1.0$ & 10.8 & $10.4 \pm 0.3$ & 6.4 & $46.1 \pm 2.1 \mathrm{~b}$ & 9.2 \\
Mixed & $107.3 \pm 3.3 \mathrm{a}$ & 8.7 & $62.3 \pm 2.9 \mathrm{~b}$ & 13.1 & $18.9 \pm 0.4$ & 6.4 & $10.1 \pm 0.3$ & 7.7 & $46.5 \pm 1.4 \mathrm{~b}$ & 8.7 \\
\hline
\end{tabular}

Note. SE - standard error, CV - coefficient of variation \%; - values with the same letter are not significantly different $(p<0.05)$.

Table 3. Variation of fresh and dry biomass yield of switchgrass populations differing in ploidy level

\begin{tabular}{|c|c|c|c|c|c|c|}
\hline \multirow{2}{*}{ Ploidy level } & \multicolumn{2}{|c|}{$1^{\text {st }}$ cut } & \multicolumn{2}{|c|}{$2^{\text {nd }}$ cut } & \multicolumn{2}{|c|}{$1^{\text {st }}+2^{\text {nd }}$ cuts } \\
\hline & mean $\pm \mathrm{SE}$ & $\mathrm{CV}$ & mean $\pm \mathrm{SE}$ & $\mathrm{CV}$ & mean $\pm \mathrm{SE}$ & $\mathrm{CV}$ \\
\hline \multicolumn{7}{|c|}{ Fresh biomass yield, g plant $^{-1}$} \\
\hline Tetraploid & $334.2 \pm 16.8 \mathrm{a}^{*}$ & 20.9 & $400.0 \pm 17.3 \mathrm{a}$ & 17.8 & $734.3 \pm 29.4 \mathrm{a}$ & 16.5 \\
\hline Octoploid & $187.8 \pm 8.7 \mathrm{~b}$ & 9.2 & $413.0 \pm 17.5 \mathrm{a}$ & 8.5 & $600.8 \pm 15.1 \mathrm{~b}$ & 5.0 \\
\hline Mixed & $268.8 \pm 15.8 \mathrm{~b}$ & 16.3 & $460.2 \pm 24.9 \mathrm{~b}$ & 15.4 & $729.0 \pm 30.0 \mathrm{a}$ & 11.8 \\
\hline \multicolumn{7}{|c|}{ Dry biomass yield, $\mathrm{g}_{\text {plant }}{ }^{-1}$} \\
\hline Tetraploid & $79.3 \pm 4.4 \mathrm{a}$ & 22.8 & $134.9 \pm 5.4$ & 16.6 & $214.2 \pm 8.4$ & 16.3 \\
\hline Octoploid & $44.3 \pm 2.3 \mathrm{~b}$ & 10.4 & $160.9 \pm 28.3$ & 35.8 & $205.2 \pm 28.2$ & 27.5 \\
\hline Mixed & $60.6 \pm 3.3 \mathrm{~b}$ & 15.3 & $154.1 \pm 9.3$ & 17.1 & $214.7 \pm 9.1$ & 12.0 \\
\hline
\end{tabular}

Note. SE - standard error, CV - coefficient of variation \%; $*^{*}$ - values with the same letter are not significantly different $(p<0.05)$.

showed that tetraploid and mixed ploidy populations accumulated significantly $(P<0.05)$ more fresh biomass compared with octoploid populations. Analysis of the dry biomass yield of the first cut revealed that tetraploid switchgrass populations maintained their superiority over octaploid and mixed ploidy populations, i.e. significantly $(P<0.05)$ outyielded them. Plants of mixed ploidy populations produced the highest $(P<0.05)$ second cut fresh biomass yield. However, the dry biomass yield of the second cut of tetraploid populations fell behind that of octoploid and mixed ploidy populations. According to the annual dry biomass yield $\left(1^{\text {st }}+2^{\text {nd }}\right.$ cuts), tetraploid and mixed ploidy populations were very similar; however, they inappreciably surpassed octaploid plants. The analysis of the first cut of dry biomass yields showed that tetraploid population significantly $(P<0.05)$ surpassed the octoploid and mixed ploidy populations. Slightly higher dry biomass yield was determined in the octoploid and mixed ploidy populations after second cut. There was no significant difference between annual ( $1^{\text {st }}$ $+2^{\text {nd }}$ cuts) dry biomass yield in tetraploid and mixed ploidy populations and was only slightly higher than in octoploid population. Population catalogue Nos. 106, 57 and 130 were distinguished for the high fresh mass yield. The fresh/dry biomass yield for these populations averaged 824.4/248.0 - 917.2/260.0 $\left(\right.$ g plant $\left.^{-1}\right)$.

The coefficient of variation of fresh biomass yield ranged from $11.8 \%$ to $20.9 \%$ in tetraploid and mixed ploidy populations; while in octoploid plants it shifted slightly - from $5.0 \%$ to $9.2 \%$. The lowest stable indication was dry biomass levels. Coefficient of variation of dry biomass yield varied from $10.4 \%$ to $35.8 \%$ in tetraploid and octoploid populations, while in mixed ploidy populations it varied just from $12.0 \%$ to $17.1 \%$. The data provided in Table 4 show that all switchgrass populations were similar in overwinter survival rate.

Table 4. Overwinter survival and heading date of switchgrass

\begin{tabular}{|c|c|c|c|c|c|}
\hline \multirow[b]{2}{*}{ Ploidy level } & \multirow{2}{*}{$\begin{array}{c}\text { Average overwinter } \\
\text { survival rate } \%\end{array}$} & \multicolumn{4}{|c|}{ Earliness } \\
\hline & & heading date & $\begin{array}{c}\text { plant } \\
\%\end{array}$ & heading date & $\begin{array}{c}\text { plant } \\
\%\end{array}$ \\
\hline Tetraploid & 96.0 & $3006-0107$ & $75.0 \mathrm{a}^{*}$ & 0807 & $25.0 \mathrm{a}$ \\
\hline Octoploid & 93.7 & $3006-0107$ & $33.3 \mathrm{~b}$ & 0807 & $66.7 \mathrm{~b}$ \\
\hline Mixed & 96.7 & $3006-0107$ & $20.0 \mathrm{~b}$ & 0807 & $80.0 \mathrm{~b}$ \\
\hline
\end{tabular}

Note. ${ }^{*}-$ values with the same letter are not significantly different $(p<0.05)$.

According to the weather data from the Dotnuva Agrometeorological Station, the winter of 2012-2013 was adverse for overwinter survival of switchgrass collections. The winter was cold, with a long-lasting snow cover and frozen soil. Notwithstanding this fact, wild switchgrass populations exhibited a good overwinter survival rate averaging 93.7-96.7\%. An insignificantly worse overwinter survival rate was recorded for the four tetraploid populations (Nos. 134, 42, 30 and 24) $89.3 \%$, two octoploid populations (Nos. 114 and 119) $85.7-89.3 \%$ and one mixed ploidy population (No. 118) $-85.7 \%$.

Tetraploid plants were characterized by earliness of maturity in our collection. Seventy five percent of tetraploid plant ears emergence started 7 days earlier than that of octoploid and mixed ploidy populations. Results of 
other studies on this issue are controversial. Cortese et al. (2010) have reported tetraploid populations to be of a later maturity compared with octoploid. Lowry et al. (2014) suggest that the phenotypic characteristics (heading, full anthesis, seed maturity dates) of switchgrass populations are largely dependent on the latitude of their origin rather than on ploidy level. We agree with the opinion that that these characteristics are determined by the interaction of various factors (origin, environment).

\section{Conclusions}

1. Wild populations of the switchgrass collection differed in ploidy level: tetraploid (genomic DNA content of $2.5 \mathrm{pg}$ ), octoploid (genomic DNA content of $5.4 \mathrm{pg}$ ) and mixed (genomic DNA content from 2.1 to $7.0 \mathrm{pg}$ ).

2. The plants of tetraploid and mixed ploidy populations produced significantly $(P<0.05)$ taller culms. According to leaf length, tetraploid plants lagged behind octoploid and mixed ploidy plants; however, tetraploids tended to form more culms. All the three groups of populations were very similar in terms of bunch diameter and leaf width.

3. Tetraploid and mixed ploidy populations accumulated significantly $(P<0.05)$ more fresh biomass compared with octoploid populations. The same trend was observed for dry biomass yield.

4. The overwinter survival rate for all populations ranged from $93.7 \%$ to $96.7 \%$. The plants of tetraploid populations exhibited earlier heading date. The highest variability was recorded for dry biomass yield (coefficient of variation 5.0-35.8\%).

\section{Acknowledgements}

This research was funded by a grant (No. MIP073/2012) from the Research Council of Lithuania.

Received 06082014 Accepted 10042015

\section{References}

Alexopoulou E., Sharma N., Paptheohari Y., Christou M., Piscioneri I., Panoutsou C., Pignatelli V. 2008. Biomass yields for upland and lowland switchgrass varieties grown in the Mediterranean region. Biomass and Bioenergy, 32 (10): 926-933

http://dx.doi.org/10.1016/j.biombioe.2008.01.015

Beale C. V., Long S. P. 1995. Can perennial C4 grasses attain high efficiencies of radiant energy conversion in cool climates? Plant, Cell and Environment, 18: 641-650 http://dx.doi.org/10.1111/j.1365-3040.1995.tb00565.x

Black C. C. 1971. Ecological implications of dividing plants into groups with distinct photosynthetic production capacities. Cragg J. B. (ed.). Advances in ecological research. New York, USA, p. 87-114

Casler M. D. 2005. Ecotypic variation among switchgrass populations from the northern USA. Crop Science, 45: 388-398 http://dx.doi.org/10.2135/cropsci2005.0388

Casler M. D. 2010. Changes in mean and genetic variance during two cycles of within-family selection in switchgrass. Bioenergy Research, 3: 47-54 http://dx.doi.org/10.1007/s12155-009-9071-9
Casler M. D. 2012. Switchgrass breeding, genetics, and genomics. Monti A. (ed.). Switchgrass: a valuable biomass crop for energy. London, New York, p. 29-53

Cortese L. M., Honig J., Miller Ch., Bonos S. A. 2010. Genetic diversity of twelve switchgrass populations using molecular and morphological markers. Bioenergy Research, 3: 262$271 \mathrm{http}: / / \mathrm{dx}$.doi.org/10.1007/s12155-010-9078-2

Costich D. E., Friebe B., Sheehan M. J., Casler M. D., Buckler E. S. 2010. Genome-size variation in switchgrass (Panicum virgatum): flow cytometry and cytology reveal rampant aneuploidy. The Plant Genome, 3 (3): 130-141 http://dx.doi.org/10.3835/plantgenome2010.04.0010

Delaney J. T., Baack E. J. 2012. Intraspecific chromosome number variation and prairie restoration - a case study in Northeast Iowa, U.S.A. Restoration Ecology, 20 (5): 576 $583 \mathrm{http}: / /$ dx.doi.org/10.1111/j.1526-100X.2011.00825.x

Dhooghe E., Van Laere K., Eeckhaut T., Leus L., Van Huylenbroeck J. 2011. Mitotic chromosome doubling of plant tissues in vitro. Plant Cell, Tissue and Organ Culture, 104 (3): 359-373 http://dx.doi.org/10.1007/s11240-010-9786-5

Fay P. A., Carlisle J. D., Knapp A. K., Blair J. M., Collins S. L. 2003. Productivity responses to altered rainfall patterns in a C4-dominated grassland. Oecologia, 137: 245-251 http://dx.doi.org/10.1007/s00442-003-1331-3

Hopkins A. A., Taliafero C. M., Murphy C. D., Christian D. 1996. Chromosome number and nuclear DNA content of several switchgrass populations. Crop Science, 36: 11921195 http://dx.doi.org/10.2135/cropsci1996.0011183X003 $600050021 \mathrm{x}$

Johnston J. S., Bennett M. D., Rayburn A. L., Galbraith D. W., Price H. J. 1999. Reference standards for determination of DNA content of plant nuclei. American Journal of Botany, 86 (5): 609-613 http://dx.doi.org/10.2307/2656569

Lowry D. B., Behrman K. D, Grabowski P., Morris G. P., Kiniry J. R., Juenger T. E. 2014. Adaptations between ecotypes and along environmental gradients in Panicum virgatum. The American Naturalist, 183 (5): 682-692 http://dx.doi.org/10.1086/675760

Lu F., Lipka A. E., Glaubitz J., Elshire R., Cherney J. H., Casler M. D., Buckler E. S., Costich D. E. 2013. Switchgrass genomic diversity, ploidy, and evolution: novel insights from a network-based SNP discovery protocol. PLoS Genetics, 9 (1), e1003215 http://dx.doi.org/10.1371/journal.pgen.1003215

Lu K., Kaeppler S. M., Vogel K., Arumuganathan K., Lee D. J. 1998. Nuclear DNA content and chromosome numbers in switchgrass. Great Plains Research, 8: 269-280

Missaoui A. M., Patersin A. H., Bouton J. H. 2006. Molecular markers for the classification of switchgrass (Panicum virgatum L.) germplasm and to assessgenetic diversity in threesynthetic switchgrass populations. Genetic Resources and Crop Evolution, 53: 1291-1302 http://dx.doi.org/10.1007/s10722-005-3878-9

Narasimhamoorthy B., Saha M. C., Swaller T., Boruton J. H. 2008. Genetic diversity in switchgrass collections assessed by EST-SSR markers. Bioenergy Research, 1: 136-146 http://dx.doi.org/10.1007/s12155-008-9011-0

Parisod Ch., Holderegger R., Brochmann Ch. 2010. Evolutionary consequences of autopolyploidy. New Phytologist, 186 (1): 5-17 http://dx.doi.org/10.1111/j.1469-8137.2009.03142.x

Parrish D. J., Fike J. H. 2005. The biology and agronomy of switchgrass for biofuels. Critical Reviews in Plant Science, 24 (5-6): 423-459 http://dx.doi.org/10.1080/07352680500316433 
Pecinka A., Suchánková P., Lysak M. A., Trávníček B., Doležel J. 2006. Nuclear DNA content variation among Central European Koeleria taxa. Annals of Botany, 98 (1): 117-122 http://dx.doi.org/10.1093/aob/mcl077

Tarakanovas P., Raudonius S. 2003. Agronominių tyrimų duomenų statistinė analizè taikant kompiuterines programas ANOVA, STAT, SPLIT-PLOT iš paketo SELEKCIJA ir IRRISTAT. Lithuanian University of Agriculture, 58 p. (in Lithuanian)

Vogel K. P., Mitchell R. B. 2008. Heterosis in switchgrass: biomass yield in swards. Crop Science, 48: 2159-216 http://dx.doi.org/10.2135/cropsci2008.02.0117

Zalapa J. E., Price D. L., Kaeppler S. M., Tobias C. M., Okada M., Casler M. D. 2011. Hierarchical classification of switchgrass genotypes using SSR and chloroplast sequences: ecotypes, ploidies, gene pools, and cultivars. Theoretical and Applied Genetics, 122 (4): 805-817 http://dx.doi.org/10.1007/s00122-010-1488-1

Zhang Y., Zalapa J. E., Jakubowski A. R., Price D. L., Acharya A., Wei Y., Brummer E. C., Kaeppler S. M., Casler M. D. 2011 (a). Post-glacial evolution of Panicum virgatum: centers of diversity and gene pools revealed by SSR markers and cpDNA sequences. Genetica, 139: 933-948 http://dx.doi.org/10.1007/s10709-011-9597-6

Zhang Y., Zalapa J. E., Jakubowski A. R., Price D. L., Acharya A., Wei Y., Brummer E. C., Kaeppler S. M., Casler M. D. 2011 (b). Natural hybrids and gene flow between upland and lowland switchgrass. Crop Science, 51: 2626-2641 http://dx.doi.org/10.2135/cropsci2011.02.0104

ISSN 1392-3196 / e-ISSN 2335-8947

Zemdirbyste-Agriculture, vol. 102, No. 2 (2015), p. 153-158

DOI 10.13080/z-a.2015.102.020

\title{
Rykštėtosios soros (Panicum virgatum L.) populiacijų DNR kiekio ir agromorfologinių požymių ịvairovė Lietuvoje
}

\author{
G. Dabkevičienė, N. Lemežienė, E. Norkevičienė, Ž. Liatukas, J. Cesevičienė, \\ R. Armonienè, B. Butkutè
}

Lietuvos agrarinių ir miškų mokslų centro Žemdirbystės institutas

\section{Santrauka}

Ieškant naujų energinių augalų, susidomèta daugiamečiu C4 fotosintezès tipo augalu - rykštetaja sora (Panicum virgatum L.). Tyrimo tikslas - ịvertinti rykštètosios soros populiacijas, nustatyti DNR (deoksiribonukleorūgšties) kiekio ir agromorfologinių požymių įvairovę.

Augalų ploidiškumas buvo nustatytas taikant tėkmės citometrijos metodą. Rykštėtosios soros kolekciją sudarè 31 ivvairaus ploidiškumo populiacija. Iš jų 17 buvo tetraploidinès - vidutiniais duomenimis, genominis DNR kiekis buvo 2,5 pikogramo (pg); 4 populiacijų individuose nustatytas oktoploidams būdingas DNR kiekis $-5,4$ pg. Kitų 10 populiacijų ploidiškumas įvairavo - augalų ląstelių branduoliuose DNR kiekis kito nuo 2,1 iki 7,0 pg. Nustatyta, kad esmingai aukštesni stiebai ir didesnis kiekis žalios biomasès būdingesni tetraploidinių bei mišraus ploidiškumo populiacijų augalams nei oktoploidiniams. Panaši tendencija nustatyta analizuojant sausos biomasès kiekị. Tyrimo duomenimis, tetraploidinių populiacijų augalams būdinga ankstesnè plaukèjimo pradžia. Visų rykštètosios soros populiacijų žiemojimas panašus - 93,7-96,7 \%. Stabiliausi požymiai - augalų aukštis, kero skersmuo, lapų plotis ir ilgis (variacijos koeficientas 4,0-9,7 \%). Didžiausia požymių įvairovė nustatyta analizuojant sausos biomasès kiekị (variacijos koeficientas 5,0-35,8 \%).

Reikšminiai žodžiai: agromorfologiniai požymiai, laukinès populiacijos, ploidiškumas, rykštetoji sora. 